\title{
PENGARUH UPAH MINIMUM TERHADAP PENYERAPAN TENAGA KERJA BIDANG INDUSTRI DI INDONESIA
}

\author{
Lina Susilowati \\ Pendidikan Ekonomi, STKIP PGRI Jombang \\ e-mail: lina.stkipjb@gmail.com \\ Dwi Wahyuni \\ Pendidikan Ekonomi, STKIP PGRI Jombang \\ email: dwiwahyuni.stkipjb@gmail.com
}

\begin{abstract}
The minimum wages policy in Indonesia raises many pros and cons. This is due to increasing the minimum wage will have an impact on increasing the income of workers, at the same time an increase in the minimum wage adds to the burden of costs on employers. Some studies saw that increasing minimum wages policy can increase employment while other studies saw e opposite results. This study aimed to analyze the effect of minimum wages on employment in the industrial sector in Indonesia for the period 2012-2017.

This study used a control variable from the supply side namely the labor force and used a quantitative approach using panel regression analysis techniques with 6 year time series data for the 2012-2017 period combined with 33 province cross section data. The results showed that the minimum wage had a negative effect on employment in the industrial sector in Indonesia for the period 20122017. Whereas the labor force control variable has a positive influence on employment.
\end{abstract}

Keywords: minimum wages, employment, panel regression

\section{PENDAHULUAN}

Sektor industri merupakan sektor kekuatan strategis dan terbukti memberikan kontribusi signifikan terhadap PDB (Produk Domestik Bruto) dan penyerapan tenaga kerja. Produk Domestik Bruto (PDB) didefinisikan sebagai total nilai atau harga pasar (market prices) dari seluruh barang dan jasa akhir (final goods and services) yang dihasilkan oleh suatu perekonomian selama kurun waktu tertentu. Produk Domestik Bruto merupakan indikator penting untuk mengetahui kondisi ekonomi di suatu negara. Apabila PDB suatu negara meningkat, maka dapat dikatakan bahwa perekonomian negara tersebut menjadi lebih baik dari tahun sebelumnya.Oleh karena itu PDB suatu negara menjadi sangat penting untuk menyatakan kondisi perekonomian sesungguhnya yang terjadi di negara tersebut.

Besarnya PDB suatu negara juga ditentukan dengan seberapa banyak lapangan usaha yang ada mampu menyerap tenaga kerja . Perkembangan penyerapan tenaga kerja di Indonesia dapat dilihat dalam Tabel 2 mengenai penyerapan tenaga kerja berdasarkan lapangan pekerjaan utama merupakan penduduk usia 15 tahun ke atas yang bekerja pada berbagai sektor perekonomian, baik sektor pertanian, industri, konstruksi, perdagangan, transportasi, pergudangan dan komunikasi, keuangan maupun sektor jasa.

Tabel 1

PDB Indonesia Atas Dasar Harga Konstan Tahun 2015-2017

\begin{tabular}{|c|c|c|c|c|}
\hline \multirow{2}{*}{ No } & \multirow{2}{*}{$\begin{array}{l}\text { Lapangan } \\
\text { Usaha }\end{array}$} & \multicolumn{3}{|c|}{ Tahun } \\
\hline & & 2015 & 2016 & 2017 \\
\hline 1 & Pertanian & $1.171 .445,8$ & $1.210 .749,8$ & $1.256 .894,3$ \\
\hline 2 & $\begin{array}{l}\text { Pertambangan } \\
\text { dan Penggalian }\end{array}$ & $767.327,2$ & $774.593,1$ & $779.925,4$ \\
\hline 3 & $\begin{array}{l}\text { Industri } \\
\text { Pengolahan }\end{array}$ & $1.934 .533,2$ & $2.016 .876,8$ & $2.103 .066,4$ \\
\hline 4 & Listrik dan Gas & $94.894,8$ & $100.009,9$ & $101.551,3$ \\
\hline 5 & Pengadaan Air & $7.369,0$ & $7.634,5$ & $7.986,4$ \\
\hline 6 & Konstruksi & $879.163,9$ & $925.062,5$ & $987.883,5$ \\
\hline 7 & $\begin{array}{l}\text { Perdanggangan } \\
\text { Besar dan } \\
\text { Eceran }\end{array}$ & $1.207 .164,5$ & $1.255 .759,4$ & $1.311 .463,7$ \\
\hline 8 & $\begin{array}{l}\text { Transportasi } \\
\text { dan } \\
\text { Pergudangan }\end{array}$ & $348.855,9$ & $374.843,4$ & $406.679,4$ \\
\hline 9 & $\begin{array}{l}\text { Penyediaan } \\
\text { Akomodasi dan } \\
\text { Makan Minum }\end{array}$ & $268.922,4$ & $282.823,4$ & $298.514,9$ \\
\hline 10 & $\begin{array}{l}\text { Informasi dan } \\
\text { Komunikasi }\end{array}$ & $421.769,8$ & $459.208,1$ & $504.278,9$ \\
\hline 11 & $\begin{array}{l}\text { Jasa Keuangan } \\
\text { dan Asuransi }\end{array}$ & $347.269,0$ & $378.193,1$ & $398.919,0$ \\
\hline 12 & Real Estate & $266.979,6$ & $279.500,5$ & $289.789,4$ \\
\hline 13 & $\begin{array}{l}\text { Jasa } \\
\text { Perusahaan }\end{array}$ & $148.395,5$ & $159.321,7$ & $172.763,8$ \\
\hline 14 & Administrasi & $310.054,6$ & $319.946,1$ & $326.526,8$ \\
\hline
\end{tabular}




\begin{tabular}{llrrr}
\hline & Pemerintahan & & & \\
\hline 15 & $\begin{array}{l}\text { Jasa } \\
\text { Pendidikan }\end{array}$ & $283.020,1$ & $293.779,7$ & $304.525,0$ \\
\hline 16 & $\begin{array}{l}\text { Jasa Kesehatan } \\
\text { dan Sosial }\end{array}$ & $97.465,8$ & $102.487,8$ & $109.448,0$ \\
\hline 17 & Jasa Lainnya & $144.904,2$ & $156.523,4$ & $170.073,7$ \\
\hline & Total & $8.699 .535,3$ & $9.097 .313,2$ & $9.530 .289,9$ \\
\hline
\end{tabular}

Sumber: BPS, Tahun 2016-2018

Berdasarkan Tabel 1 dan Tabel 2 terlihat bahwa kontribusi sektor Industri terhadap PDB di Indonesia tidak sebanding dengan daya serap tenaga kerjanya. Sektor industri yang merupakan leading sector mempunyai PDB yang paling tinggi dibanding dengan sektor-sektor yang lain akan tetapi, sektor tersebut hanya mampu menduduki peringkat keempat dalam penyerapan tenaga kerjanya setelah sektor pertanian dan sektor perdagangan besar, eceran, rumah makan, dan hotel, dan sektor jasa kemasyarakatan, sosial dan perorangan.

\section{Tabel 2}

Penduduk 15 Tahun Ke Atas Yang Bekerja Menurut Lapangan Pekerjaan Utama Tahun 2015-2017

\begin{tabular}{|c|c|c|c|c|}
\hline \multirow{2}{*}{ No } & \multirow{2}{*}{$\begin{array}{c}\text { Lapangan } \\
\text { Usaha }\end{array}$} & \multicolumn{3}{|c|}{ Tahun } \\
\hline & & 2015 & 2016 & 2017 \\
\hline 1 & Pertanian & 37.748 .228 & 37.770 .165 & 35.923 .886 \\
\hline 2 & $\begin{array}{l}\text { Pertambangan } \\
\text { dan } \\
\text { Penggalian }\end{array}$ & 1.320 .466 & 1.476 .484 & 1.391 .690 \\
\hline 3 & $\begin{array}{l}\text { Industri } \\
\text { Pengolahan }\end{array}$ & 15.255 .099 & 15.540 .234 & 17.008 .865 \\
\hline 4 & $\begin{array}{l}\text { Listrik, Gas, } \\
\text { dan Air } \\
\text { Minum }\end{array}$ & 288.691 & 357.207 & 393.873 \\
\hline 5 & Konstruksi & 8.208 .086 & 7.978 .567 & 8.136 .636 \\
\hline 6 & $\begin{array}{l}\text { Perdagangan, } \\
\text { Hotel, } \\
\text { Restoran } \\
\end{array}$ & 25.686 .342 & 26.689 .630 & 28.173 .571 \\
\hline 7 & $\begin{array}{l}\text { Pengangkutan } \\
\text { dan } \\
\text { Komunikasi }\end{array}$ & 5.106 .817 & 5.608 .749 & 5.759 .684 \\
\hline 8 & $\begin{array}{l}\text { Keuangan, } \\
\text { Asuransi, } \\
\text { Usaha } \\
\text { Persewaan } \\
\text { Bangunan } \\
\end{array}$ & 3.266 .538 & 3.531 .525 & 3.752 .262 \\
\hline 9 & $\begin{array}{l}\text { Jasa } \\
\text { Kemasyarakat, } \\
\text { Sosial, dan } \\
\text { Perorangan } \\
\end{array}$ & 17.938 .926 & 19.459 .412 & 20.481 .956 \\
\hline & Total & 114.819 .199 & 118.411 .973 & 121.022 .423 \\
\hline
\end{tabular}

Sumber: BPS, Tahun 2016-2018

Tabel 3 menunjukkan perkembangan rata-rata upah minimum propinsi dari tahun 2012-2017. Kebijakan upah minimum berdampak pada tingkat pendapatan. Berdasarkan konsep neoclassical model of labor leisure choice bahwa faktor yang mendorong seorang tenaga kerja menawarkan hingga berapa lama waktu ia bekerja di pasar tenaga kerja ditentukan oleh kombinasi antara tingkat konsumsi seorang tenaga kerja (C) dan waktu luang/leisure (L) yang diperoleh hingga mencapai tingkat kepuasan/utility tertentu (Borjas, 2000).

Penetapan kebijakan upah minimum ditujukan untuk meningkatkan upah para pekerja yang masih berpendapatan di bawah upah minimum. Jika tidak ada hal-hal lain yang berubah, maka upah rata-rata semua pekerja juga akan meningkat. Namun, kenyataannya tidaklah sesederhana itu. Berdasarkan Tabel 3 rata-rata upah minimum propinsi dari tahun $2012-2017$ terus mengalami peningkatan.

Tabel 3

Rata-rata Upah Minimum Propinsi Tahun 2012-2017

\begin{tabular}{cc}
\hline Tahun & $\begin{array}{c}\text { Rata-rata Upah } \\
\text { Minimum }\end{array}$ \\
\hline 2012 & 1.088 .903 \\
\hline 2013 & 1.296 .908 \\
\hline 2014 & 1.584 .391 \\
\hline 2015 & 1.790 .342 \\
\hline 2016 & 1.997 .819 \\
\hline 2017 & 2.142 .855 \\
\hline
\end{tabular}

Sumber: BPS, Tahun 2016-2018

Penetapan kebijakan upah minimum ditujukan untuk meningkatkan upah para pekerja yang masih berpendapatan di bawah upah minimum. Jika tidak ada hal-hal lain yang berubah, maka upah rata-rata semua pekerja juga akan meningkat. Namun, kenyataannya tidaklah sesederhana itu. Berdasarkan Tabel 3 rata-rata upah minimum propinsi dari tahun 2012 -2017 terus mengalami peningkatan.

Beberapa penelitian, Pratomo (2010), Pusposari (2010) dan Chengis, Dube, Lindner and Zipperer (2019) menunjukkan bahwa upah minimum berpengaruh negatif terhadap penyerapan tenaga kerja secara statistik. Hal ini berarti bahwa setiap kenaikan upah minimum mengakibatkan pengurangan penyerapan tenaga kerja.

Akan tetapi dalam penelitian yang dilakukan oleh Marginean and Chenic (2013) menunjukkan sedikit atau tidak ada dampak kenaikan upah minimum terhadap lapangan kerja. Begitu juga dalam penelitian Lemos (2009) yang menunjukkan bahwa kenaikan upah minimum berdampak pada 
distribusi upah akan tetapi tidak mempengaruhi penyerapan tenaga kerja.

Perdebatan mengenai upah minimum dari tahun ke tahun selalu menimbulkan pro dan kontra. Para pendukung kebijakan upah minimum berpendapat bahwa pertama upah minimum diperlukan untuk memenuhi kebutuhan hidup yang layak bagi pekerja, kedua upah minimum dapat mencegah para pengusaha monopsonistik dalam mengeksploitasi pekerja yang mempunyai keterampilan rendah (low skilled), yang kebanyakan adalah wanita (Macpherson, Brue, McConnell, 2003).

Beberapa alasan dari pendapat yang tidak mendukung adanya kebijakan upah minimum adalah pertama upah minimum akan menurunkan penyerapan tenaga kerja khususnya remaja dan wanita. Kedua, upah minimum menyebabkan dampak spilover sehingga menurunkan tingkat upah pada sektor uncovered. Ketiga upah minimum mendorong remaja untuk putus sekolah (Macpherson, Brue, McConnell, 2003).

Teori permintaan tenaga kerja menunjukkan bahwa jumlah tenaga kerja yang diminta berbanding terbalik dengan upah, sedangkan perusahaan yang menghendaki keuntungan maksimum dapat memilih jumlah tenaga kerja yang menjadikan Value Marginal Physycal Produk of labor (VMPP) atau nilai pertambahan marginal tenaga kerja dikalikan dengan harga jual barang yang diproduksikan per unit sama dengan upah. Lebih lanjut perusahaan akan menyesuaikan jumlah tenaga kerja yang digunakan dengan perubahan biaya tenaga kerja (Bellante. D. and Jackson. M., 1990).

Menurut Borjas (2000), elastisitas digunakan untuk mengukur respon permintaan tenaga kerja dalam industri jika terjadi perubahan tingkat upah. Elastisitas jangka pendek dari permintaan tenaga kerja didefinisikan sebagai perubahan presentase tenaga kerja dalam jangka pendek $\left(\mathrm{E}_{\mathrm{SR}}\right)$ akibat dari perubahan 1 persen dalam tingkat upah.

Angkatan kerja dapat diukur dengan rumus berikut (Borjas, 2000):

$$
\mathbf{L F}=\mathbf{E}+\mathbf{U}
$$

Dimana $L F$ adalah angkatan kerja, $E$ adalah jumlah orang yang dianggap employed, dan $\mathrm{U}$ adalah jumlah orang yang dianggap unemployed. Seseorang yang bekerja maupun tidak bekerja juga disebut sebagai angkatan kerja.

Secara keseluruhan, upah minimum di Indonesia selalu mengalami kenaikan yang sifatnya monoton diikuti oleh fluktuasi penyerapan tenaga kerja yang tidak terlalu menonjol di beberapa sektor. Oleh karena itu, penelitian ini lebih memfokuskan mengenai bagaimana pengaruh kenaikan upah minimum terhadap penyerapan tenaga kerja di bidang industri di Indonesia periode tahun 2012-2017?

\section{Hipotesis Penelitian}

Hipotesis dalam penelitian ini adalah sebagai berikut :Upah minimum berpengaruh secara negative terhadap penyerapan tenaga kerja bidang industri di Indonesia periode tahun 2012-2017.

\section{METODE PENELITIAN \\ Pendekatan Penelitian}

Penelitian ini merupakan penelitian kuantitatif, yaitu penelitian yang bertujuan untuk menguji hipotesis dengan menggunakan analiss dari data statistic yang dikumpulkan dalam penelitian.

\section{Jenis dan Metode Pengumpulan Data}

Untuk mendukung penelitian mengenai pengaruh kenaikan upah minimum terhadap penyerapan tenaga kerja di bidang industri, peneliti menggunakan data panel 33 provinsi di seluruh Indonesia sejak tahun 2012-2017.

Data yang digunakan dalam penelitian ini adalah data sekunder yang didapatkan dari Badan Pusat Statistik (BPS) meliputi data penyerapan tenaga kerja di sektor industri, data upah minimum provinsi dan angkatan kerja.

\section{Definisi dan Pengukuran Variabel}

Untuk memudahkan memahami variabel yang digunakan dalam penelitian ini maka berikut disajikan Tabel 4 tentang definisi dan pengukuran variabel penelitian.

\section{Teknik Analisa Data}

Dalam penelitian ini tehnik estimasi model penelitian yang digunakan adalah pendekatan data panel. Ada tiga metode yang bisa digunakan untuk bekerja dengan data panel.

Pertama, adalah pendekatan pooled least square (PLS) secara sederhana menggabungkan (pooled) seluruh data time series dan cross section.

Kedua, pendekatan fixed effect memperhitungkan kemungkinan bahwa peneliti menghadapi masalah omitted variables dimana omitted variables mungkin membawa perubahan pada intercept time series atau cross section. Model dengan fixed effect menambahkan dummy 
variables untuk membolehkan adanya perubahan intercept ini.

Ketiga, pendekatan efek acak (random effect) memperbaiki efisiensi proses least square dengan memperhitungkan error dari cross section dan time series. Model random effect adalah variasi dari estimasi generalized least square. Model data panel untuk masing-masing tehnik regresi adalah sebagai berikut (Gujarati, 2003):
a. Pooled Least Square
$\mathrm{Y}_{\mathrm{it}}=\beta_{1}+\beta_{2}+\beta 3 \mathrm{X}_{3 \mathrm{it}}+\ldots . .+\beta_{\mathrm{n}} \mathrm{X}_{\mathrm{nit}}+\mathrm{u}_{\mathrm{it}}$
b. Fixed Effect
$\mathrm{Y}_{\mathrm{it}}=\alpha_{1}+\alpha_{2} \mathrm{D}_{2}+\ldots \ldots+\alpha_{\mathrm{n}} \mathrm{D}_{\mathrm{n}}+\beta_{2} \mathrm{X}_{2 \mathrm{it}}+\ldots . .+\beta_{\mathrm{n}} \mathrm{X}_{\text {nit }}$
$+\mathrm{u}_{\mathrm{it}}$
c. Random Effect
$\mathrm{Y}_{\mathrm{it}}=\beta_{1}+\beta_{2} \mathrm{X}_{2 \mathrm{it}}+\ldots \ldots \ldots+\beta_{\mathrm{n}} \mathrm{X}_{\mathrm{nit}}+\varepsilon_{\mathrm{it}}+\mathrm{u}_{\mathrm{it}}$

\section{Tabel 4}

Definisi dan Ukuran Variabel

\begin{tabular}{|c|c|c|}
\hline Variabel & Definisi & Ukuran \\
\hline $\begin{array}{l}\text { Penyerapan } \\
\text { Tenaga Kerja }\end{array}$ & $\begin{array}{lr}\text { Penduduk } & 15 \\
\text { tahun ke atas yang } \\
\text { bekerja di } & \text { sektor } \\
\text { industri } & \text { selama } \\
\text { satu tahun } & \end{array}$ & $\begin{array}{l}\text { Total penduduk } \\
15 \text { tahun ke atas } \\
\text { yang bekerja di } \\
\text { sektor industri } \\
\text { dalam satu tahun } \\
\text { (bentuk log } \\
\text { natural) }\end{array}$ \\
\hline Angkatan Kerja & $\begin{array}{lr}\text { Penduduk } & 15 \\
\text { tahun ke atas yang } \\
\text { mencari kerja, } \\
\text { mempersiapkan } \\
\text { usaha, merasa } \\
\text { tidak mungkin } \\
\text { mendapat } \\
\text { pekerjaan dan } \\
\text { sudah punya } \\
\text { pekerjaan tetapi } \\
\text { belum } \\
\text { bekerja }\end{array}$ & $\begin{array}{l}\text { Total penduduk } \\
15 \text { tahun ke atas } \\
\text { yang mencari } \\
\text { kerja, } \\
\text { mempersiapkan } \\
\text { usaha, merasa } \\
\text { tidak mungkin } \\
\text { mendapat } \\
\text { pekerjaan dan } \\
\text { sudah punya } \\
\text { pekerjaan tetapi } \\
\text { belum mui } \\
\text { bekerja } \\
\text { dihitung selama } \\
\text { satu } \\
\text { (bentuk tahun } \\
\text { natural) }\end{array}$ \\
\hline Upah Minimum & $\begin{array}{l}\text { Upah Minimum } \\
\text { Propinsi }\end{array}$ & $\begin{array}{l}\text { Upah Minimum } \\
\text { Propinsi per } \\
\text { bulan (bentuk } \\
\text { log natural) }\end{array}$ \\
\hline
\end{tabular}

Sumber: review literatur

\section{Pemilihan Model Estimasi dalam Data Panel}

Dari tiga pendekatan metode data panel, dua pendekatan yang sering digunakan untuk mengestimasi model regresi dengan data panel adalah pendekatan fixed effect model dan pendekatan random effect model.
Untuk menentukan metode antara pooled least square dan fixed effect dengan menggunakan uji $\mathrm{F}$ sedangkan uji Hausman digunakan untuk memilih antara random effect atau fixed effect. Dalam fixed effect, bentuk umum regresi data panel adalah (Aulia, 2004):

$\mathrm{Y}_{\mathrm{it}}=\beta_{1}+\beta_{2} \mathrm{X}_{\mathrm{it}}+\beta_{3} \mathrm{X}_{3 \mathrm{it}}+\ldots \ldots+\beta_{\mathrm{n}} \mathrm{X}_{\mathrm{nit}}+\mathrm{u}_{\mathrm{it}}$

Selain itu, dalam teknik estimasi model regresi data panel, terdapat Redundant Fixed Effect Test dan Haussman Test. Redundant Fixed Effect Test digunakan untuk memilih teknik dengan model pooled least square (PLS) atau model fixed effect

Hipotesis nol dari pada Redundant Fixed Effect Test adalah:

$$
\begin{aligned}
& \mathrm{H}_{0}=\text { Model Pooled Least Square } \\
& \mathrm{H}_{1}=\text { Model Fixed Effect }
\end{aligned}
$$

Dari rumus diatas, jika kita mendapatkan hasil prob. Cross Section F kurang dari 0,05 maka kita menolak hipotesis $\mathrm{H}_{0}$ dan menerima hipotesis $\mathrm{H}_{1}$ yang menyatakan kita harus menggunakan model Fixed Effect untuk teknik estimasi dalam penelitian ini.

Sedangkan Haussman Test digunakan untuk memilih antara metode fixed effect atau metode random effect dengan melihat nilai Chi Square pada uji Hausman. adalah:

Hipotesis nol dari pada Haussman Test

$\mathrm{H}_{0}=$ random effect

$\mathrm{H}_{1}=$ fixed effect

Apabila Chi Square untuk p-value signifikan maka $\mathrm{H}_{0}$ ditolak dan model fixed effect lebih tepat untuk digunakan (Aulia, 2004). Uji Hausman juga dapat dilakukan melalui command program reviews 7 .

\section{Model Penelitian}

Pengaruh kenaikan upah minimum terhadap penyerapan tenaga kerja di sektor industri difokuskan pada tenaga kerja yang secara legal mengikuti peraturan kebijakan upah minimum yang ditetapkan oleh pemerintah, maka model penelitiannya adalah sebagai berikut:

$\ln Y_{i t}=\beta_{0}+\beta_{1} \ln X_{1 i t}+\psi \ln X_{2 i t}+\gamma_{i,+} v_{t}+\varepsilon_{i t}$

Dimana:

LnY : Jumlah total tenaga kerja yang bekerja di bidang industri 


$\begin{array}{lll}\operatorname{LnX}_{1} & : \text { Upah minimum propinsi riil } \\ \mathrm{i} & : \text { Propinsi } \\ \mathrm{t} & : \text { Tahun } \\ \beta_{0} & : \text { Konstanta } \\ \beta_{1} & : \text { Parameter } \\ \psi & : \text { Parameter variabel control dari sisi } \\ & & \text { penawaran } \\ \mathrm{LnX}_{2} & : \text { Variabel kontrol dari sisi penawaran } \\ & & \text { yaitu proporsi angkatan kerja } \\ \gamma_{i,} & : \text { Individual spesifik } \\ v_{t} & : \text { Time spesifik } \\ \varepsilon & : \text { Error term }\end{array}$

\section{Pengujian statistik}

Untuk menguji hipotesis penelitian dilakukan pengujian sebagai berikut :

\section{Uji $R^{2}$}

Kegunaan dari uji $R^{2}$ ini adalah untuk menunjukkan apakah variabel independennya dapat menerangkan variabel dependennya dengan baik. Nilai $R^{2}$ berkisar antara $0-1$. Suatu model time series apabila $R^{2}$ mencapai angka 1 maka variabel independennya dapat menerangkan variabel dependen dengan sempurna. Sebaliknya apabila $R^{2}$ mencapai angka 0 berarti variabel independennya tidak dapat atau lemah dalam menerangkan variabel dependen.

\section{Uji $t$}

Fungsi uji $t$ adalah untuk menentukan signifikansi suatu variabel bebas secara individual dalam mempengaruhi variabel tidak bebas. Dalam hal ini diterapkan hipotesis sebagai berikut:

$$
\begin{aligned}
& \mathrm{H}_{0}: \beta_{1}=0 \\
& \mathrm{H}_{1}: \beta_{1} \neq 0
\end{aligned}
$$

Apabila $t_{0}\left(t_{\text {hitung }}\right)<\left(t_{\text {tabel }}\right)$ maka hipotesis nol $\left(\mathrm{H}_{0}\right)$ diterima dan hipotesis alternatif $\left(\mathrm{H}_{1}\right)$ ditolak artinya model yang digunakan kurang baik, dengan kata lain variabel bebas tidak dapat menerangkan variabel terikatnya atau tidak signifikan. Sebaliknya jika $t_{0}\left(t_{\text {hitung }}\right)>\left(t_{\text {tabel }}\right)$ maka dapat dikatakan bahwa variabel bebas dapat menerangkan variabel terikatnya atau signifikan.

\section{Uji $\boldsymbol{F}$}

Kegunaan uji $F$ untuk menentukan signifikan atau tidak signifikannya suatu variabel bebas secara bersama-sama dalam mempengaruhi variabel tidak bebas. Dalam hal ini ditetapkan sebagai berikut :

$\mathrm{H}_{0}: \beta_{1}=\beta_{2}=\beta_{3}=\beta_{k}=0$
$\mathrm{H}_{1}: \beta_{1} \neq \beta_{2} \neq \beta_{3} \neq \beta_{k} \neq 0$

Jika hasil perhitungan ternyata, $F_{0}\left(F_{\text {hitung }}\right)<$ $(F$ tabel $)$, maka hipotesis nol $\left(\mathrm{H}_{0}\right)$ diterima dan hipotesis alternatif $\left(\mathrm{H}_{0}\right)$ ditolak. Bila terjadi keadaan demikian, dapat dikatakan bahwa variasi dari model regresi tidak berhasil menerangkan variabel bebasnya. Sebaliknya, jika $F_{0}\left(F_{\text {hitung }}\right)>$ $(F$ tabel $)$ maka dapat dikatakan hipotesis nol $\left(\mathrm{H}_{0}\right)$ ditolak dan hipotesis alternatif $\left(\mathrm{H}_{0}\right)$ diterima. Bila terjadi keadaan demikian dikatakan bahwa variasi dari model regresi dapat menerangkan variasi variabel bebasnya.

\section{Uji Asumsi Klasik}

Untuk mengetahui apakah model analisis yang kita gunakan bebas dari penyimpangan asumsi klasik sehingga model analisis tidak bias (unbiased) atau bisa diterima, maka dilakukan uji multikollinearitas dan uji heteroskedastisitas. Uji Autokorelasi tidak diperlukan mengingat analisis data panel dengan menggunakan fixed effect model (FEM) tidak membutuhkan asumsi terbebasnya model dari serial korelasi (Nachrowi dan Usman, 2002).

\section{Uji Multikolinearitas}

Uji multikolinearitas digunakan untuk menguji suatu model apakah terjadi hubungan linier yang "sempurna" atau "hampir sempurna" diantara beberapa variabel bebas, sehingga sulit memisahkan pengaruh antara variabel bebas secara individu terhadap variabel terikat.

Untuk mengetahui ada atau tidaknya multikolinearitas menggunakan eviews 7.0, maka salah satu cara adalah dengan melihat korelasi diantara variabel-variabel independent. Jika korelasinya kurang dari 0,9 maka dikatakan tidak ada multikollinearitas (Ghozali, 2013).

\section{Uji Heteroskedastisitas}

Dalam ekonometrika, situasi dimana varian $\left(\sigma^{2}\right)$ dari faktor pengganggu $\varepsilon_{\text {it }}$ atau erro terms, atau disturbance error adalah sama untuk semua observasi atau pengamatan terhadap independent variabel (Xi) ini diisebut dengan homoskedastisitas (homoscedasticity) atau varian yang sama.

Bila nilai varian dari dependent variable (Yi) meningkat sebagai akibat meningkatnya varian dari independent variable maka varian dari $\mathrm{Yi}$ tidak sama. Dalam ekonometrika, hal ini disebut dengan kondisi heteroskedastisitas. Hakekat heteroskedastisitas adalah varian dari error term 
tidak konstan atau ada korelasi error term dengan variabel independentnya.

$\operatorname{cov}\left(\mu_{\mathrm{I}}, \mathrm{X}_{\mathrm{i}}\right)=0 \operatorname{cov}\left(\mu_{\mathrm{I}}, \mathrm{X}_{\mathrm{i}}\right) \neq 0$

e $\left(\mu_{\mathrm{i}}^{2}\right)=\sigma^{2} \rightarrow$ homokedastisitas (konstan) e $\left(\mu_{\mathrm{i}}^{2}\right)$

$\neq \sigma^{2} \rightarrow$ heteroskedastisitas

Jika hasil uji $\mathrm{F}$ pada koefisien regresi > nilai signifikansi, maka berarti tidak terjadi pengaruh yang signifikan antara nilai-nilai $\mathrm{X}$ dengan nilai absolut residual, sehingga disimpulkan bahwa asumsi tidak terjadi heteroskedastisitas dengan uji Glejser dapat terpenuhi.

\section{PEMBAHASAN}

Berikut ini adalah tahapan tahapan dalam pengujian statisik dan pembahasannya.

\section{Pemilihan Model}

Berdasarkan tehnik analisa regresi panel dapat diestimasi dengan tiga metode estimasi yaitu pooled least square (PLS) atau common effect model, fixed effect model (FEM), dan random effect model (REM), dimana dua metode terakhir disebut GLS. Hasil uji Redundant Fixed Effect dilakukan untuk menentukan model yang tepat antara pooled least square (PLS) atau fixed effect model (FEM), dalam mengestimasi pengaruh upah minimum terhadap penyerapan tenaga kerja di Indonesia.

Hasil Redundant Fixed Effect Test untuk menentukan estimasi model dimana hipotesisnya adalah:

H0: Metode PLS,

H1: Metode FEM.

Hasil Redundant Fixed Effect Test diperoleh niai Chi Square sebesar 0,0000 kurang dari 0,05 sehingga menolak $\mathrm{H} 0$ dan menerima $\mathrm{H} 1$ sehingga keputusannya adalah menggunakan metode Fixed Effect Model (FEM).

Langkah berikutnya adalah memilih model yang tepat untuk mengetahui pengaruh upah minimum terhadap penyerapan tenaga kerja di Indonesia, apakah menggunakan FEM atau REM. Uji Hausman untuk mengetahui model yang tepat digunakan dengan menggunakan hipotesis:

\section{H0: REM dan \\ $\mathrm{H} 1$ :FEM.}

Hasil Hausman Test menunjukkan probabilitas sebesar 0,0000 kurang dari 0,05, sehingga $\mathrm{H} 0$ ditolakdan $\mathrm{H} 1$ diterima sehingga model yang tepat digunakan untuk mengestimasi pengaruh upah minimum terhdapat penyerapan tenaga kerja di Indonesia adalah Fixed Effect Model (FEM).

\section{Hasil Estimasi Model Pengaruh Upah Minimum Terhadap Penyerapan Tenaga Kerja Bidang Industri Di Indonesia}

Berdasarkan hasil Redundant Fixed Effect Test dan Hausman Test, Model yang terpilih untuk mengestimasi pengaruh upah minimum terhadap penyerapan tenaga kerja di Indonesia adalah Fixed Effect Model (FEM).

Hasil estimasi model fixed effect menunjukkan nilai R-square 0.938274 atau 93,82 persen. Hal ini berarti bahwa variasi total variabel penyerapan tenaga kerja sebesar 93,82 persen dapat dijelaskan oleh variabel upah minimum dan angkatan kerja.

\section{Tabel 5}

\begin{tabular}{|c|c|c|c|}
\hline \multicolumn{4}{|c|}{$\begin{array}{c}\text { Hasil Fixed Effect Model Pengaruh Upah } \\
\text { Minimum Terhadap Penyerapan Tenaga } \\
\text { Kerja Bidang Industri Di Indonesia }\end{array}$} \\
\hline Variabel & Coefficient & T Statistic & Prob \\
\hline $\mathrm{C}$ & 8.887696 & 19.72686 & 0.0000 \\
\hline $\mathrm{X}_{1}$ & -0.129885 & -2389945 & 0.0180 \\
\hline $\mathrm{X}_{2}$ & 0.306006 & 6.562598 & 0.0000 \\
\hline \\
\hline \multicolumn{4}{|c|}{72.87338} \\
\hline \multicolumn{4}{|c|}{ Prob (F-statistic) 0.000000} \\
\hline
\end{tabular}

Sumber: Data diolah peneliti

Uji statistik $\mathrm{t}$ digunakan untuk mengetahui apakah variabel bebas upah minimum dan angkatan kerja yang dimasukkan ke dalam model secara parsial berpengaruh terhadap variabel terikat penyerapan tenaga kerja.

Berdasarkan hasil analisis regresi panel diketahui bahwa probabilitas $\mathrm{t}$ statistic untuk variabel $\mathrm{X}_{1}$ (upah minimum) sebesar 0.0180 kurang dari 0,05 atau (signifikan di $\alpha=5$ persen) dengan arah negatif. Hal ini berarti bahwa variabel upah minimum berpengaruh terhadap penyerapan tenaga kerja di Indonesia. Variabel control $\left(\mathrm{X}_{2}\right)$ angkatan kerja menunjukkan probabilitas t statistik sebesar 0,0000 kurang dari 0,01 atau (signifikan di $\alpha=1$ persen) dengan arah positif. Hal ini berarti bahwa variabel angkatan kerja berpengaruh terhadap penyerapan tenaga kerja di Indonesia.

Hasil uji $F$ statistik digunakan untuk mengetahui apakah variabel bebas upah minimum dan angkatan kerja yang dimasukkan ke dalam model secara simultan berpengaruh terhadap variabel terikat penyerapan tenaga kerja di Indonesia. Berdasarkan tabel di atas diketahui 
bahwa probabilitas $\mathrm{F}$ statistic untuk menunjukkan nilai 0,0000 kurang dari 0,01 atau (signifikan di $\alpha$ $=1$ persen). Hal ini berarti bahwa variabel bebas upah minimum dan angkatan kerja yang dimasukkan ke dalam model secara simultan berpengaruh terhadap variabel terikat penyerapan tenaga kerja di Indonesia.

Untuk menggambarkan upah minimum di Indonesia ditunjukkan oleh angka koefisien $\mathrm{X}_{1}$ sebesar -0.129885. Hal ini berarti bahwa ketika upah minimum dinaikkan 1 persen sedangkan variabel control angkatan kerja dianggap konstan maka akan terjadi penurunan penyerapan tenaga kerja sebesar 0,129 persen. Koefisien variable kontrol angkatan kerja $\left(\mathrm{X}_{2}\right)$ sebesar 0.306006, menggambarkan elastisitas angkatan kerja. Hal ini berarti bahwa ketika angkatan kerja dinaikan sebesar 1 persen sedangkan variabel upah minimum dianggap konstan maka akan diikuti oleh kenaikan penyerapan tenaga kerja sebesar 0,306 persen.

Hasil regresi fixed effect model juga menunjukkan nilai individual effect. Dari 33 propinsi yang dimasukkan ke dalam penelitian diatas tujuh belas propinsi memiliki nilai individual effect positif sedangkan di enam belas propinsi memiliki nilai individual effect negative. Propinsi yang memiliki nilai individual effect positif berarti bahwa ketika terjadi kenaikan upah minimum dan angkatan kerja pada propinsi tersebut maka akan diikuti oleh kenaikan penyerapan tenaga kerja, sedangkan Propinsi yang memiliki nilai individual effect negatif berarti bahwa ketika terjadi kenaikan upah minimum dan angkatan kerja pada propinsi tersebut maka akan menyebabkan terjadinya penurunan penyerapan tenaga kerja.

\section{Uji Asumsi Klasik}

\section{Uji Multikollinearitas}

Multikollinearitas merupakan peristiwa dimana terdapat hubungan linier diantara variabel bebas di dalam regresi. Untuk mendeteksi adanya multikollinearitas di dalam model perlu dilakukan analisis matriks korelasi diantara variable bebas. Jika diantara variable bebas memiliki korelasi kurang dari 0,9 maka dapat dikatakan tidak terjadi multikollinearitas.

Berdasarkan Tabel 6 diketahui bahwa koefisien korelasi antara $X_{1}$ dan $X_{2}$ sebesar 0,64 kurang dari 0,9 sehingga dapat dinyatakan bahwa tidak ada multikollinearitas dalam model.

\section{Tabel 6} Hasil Uji Multikollinearitas

\begin{tabular}{ccc}
\hline $\begin{array}{c}\text { Variabel } \\
\text { Independen }\end{array}$ & $\mathbf{X}_{\mathbf{1}}$ & $\mathbf{X}_{\mathbf{2}}$ \\
\hline $\mathrm{X}_{1}$ & 1 & 0.64500003 \\
\hline $\mathrm{X}_{2}$ & 0.64500003 & 1 \\
\hline
\end{tabular}

\section{Uji Heteroskedastisitas}

Pada analisis regresi data panel dengan menggunakan fixed effect model (FEM) tidak diperbolehkan adanya gejaa heteroskedastisitas yaitu varians berubah dari satu pengamatan ke pengamatan yang lain (varians tidak konstan). Dalam penelitian uji heteroskedastisitas menggunakan uji Glejser.

Apabila nilai Prob. Chi suare (2) pada Obs*RSquared lebih besar dari 0,05 dikatakan menolak $\mathrm{H} 0$ dan menerima $\mathrm{H} 1$ atau regesi bersifat homoskedastisitas atau dengan kata lain model terbebas dari penyimpangan asumsi heteroskedastisitas. Sebaliknya apabila nilai Prob. Chi suare (2) pada Obs*R-Squared kurang dari 0,05 dikatakan H0 diterima, H1 ditolak ditolak atau terdapat gejala heteroskedastisitas didalam model. Atau dengan melihat prob.F apabila lebih besar dari 0,05 dikatakan menolak $\mathrm{H} 0$ dan menerima $\mathrm{H} 1$ artinya tidak terdapat heteroskedastisitas di dalam model dan sebaliknya.

Berdasarkan Tabel 7, hasil uji heteroskedastisitas menunjukkan nilai nilai Prob. Chi suare (2) pada Obs*R-Squared sebesar 0.3134 lebih besar dari 0,05 dikatakan menolak $\mathrm{H} 0$, dan menerima H1, artinya model bebas dari penyimpangan heteroskedastisitas. Dapat pula ditunjukkan pada nilai prob.F sebesar 0.4802 dikatakan menolak $\mathrm{H} 0$, dan menerima $\mathrm{H} 1$ sehingga dikatakan tidak terdapat heteroskedastisitas dalam model.

Tabel 7

Hasil Uji Heteroskedastisitas

\begin{tabular}{|c|c|c|c|}
\hline \multicolumn{4}{|c|}{ Heteroskedasticity Test: Glejser } \\
\hline F-statistic & 0,946184 & $\begin{array}{l}\text { Prob. F } \\
(2,3)\end{array}$ & 0,4802 \\
\hline Obs*R-squared & 2,320799 & $\begin{array}{l}\text { Prob. Chi- } \\
\text { Square(2) }\end{array}$ & 0,3234 \\
\hline Scaled explained SS & 1,052158 & $\begin{array}{l}\text { Prob. Chi- } \\
\text { Square(2) }\end{array}$ & 0,5909 \\
\hline
\end{tabular}

Sumber: Data diolah

Pembahasan Pengaruh Upah Minimum Terhadap Penyerapan Tenaga Kerja Bidang Industri Di Indonesia Periode 2012-2017

Berdasarkan hasil uji panel least square dengan metode Fixed Effect Model (FEM) menunjukkan bahwa upah minimum berpengaruh 
negative terhadap penyerapan tenaga kerja di Indonesia periode 2012-2017. Hal ini berarti bahwa ketika terjadi kenaikan upah minimum maka berdampak pada pengurangan penyerapan tenaga kerja.

Hal ini didukung oleh teori ketenagakerjaan yang menyatakan bahwa jumlah tenaga kerja yang diminta berbanding terbalik dengan upah, sedangkan perusahaan yang menghendaki keuntungan maksimum dapat memilih jumlah tenaga kerja yang menjadikan nilai pertambahan marginal tenaga kerja dikalikan dengan harga jual barang yang diproduksikan per unit sama dengan upah. Lebih lanjut perusahaan akan menyesuaikan jumlah tenga kerja yang digunakan dengan perubahan biaya tenaga kerja (Bellante D \& Jackson, 1990).

Hasil penelitian ini juga selaras dengan teori permintaan tenaga kerja jangka pendek untuk sebuah industri. Setiap perusahaan dalam persaingan sempurna tidak dapat mempengaruhi harga. Akan tetapi perusahaan dalam industri mengambil keuntungan dari upah yang lebih rendah dengan meningkatkan jumlah pekerja, yang berarti akan ada lebih banyak output yang dihasilkan. Banyaknya output akan menyebabkan penurunan harga output yang berarti bahwa nilai tambah produk marjinal juga akan turun, dan menggeser kurva permintaan tenaga kerja untuk masing-masing perusahaan ke kiri (Borjas, 2000).

Menurut (Borjas, 2000) kurva permintaan tenaga kerja dalam jangka pendek memiliki slop negatif, maka elastisitas tenaga kerjanya pun negatif. Misalkan upah mula - mula adalah \$20 dengan 56 pekerja. Apabila terjadi kenaikan upah hingga upah sekarang adalah $\$ 30$, maka elastisitas tenaga kerja akan turun sebesar -1,733.

Hasil penelitian ini didukung pula oleh beberapa penelitian terdahulu. Pertama adalah penelitian dari (Addison $\mathrm{J} \mathrm{T}$ and Azturk $\mathrm{O} \mathrm{D}$, 2010), dalam Minimum Wages, Labor Market Institutions, and Female Employment and Unemployment; Cross Country analysis, memperkirakan dampak peraturan upah minimum di 16 negara OECD, 1970 - 2008.

Penelitian ini menggunakan metode panel untuk memperkirakan dampak upah minimum di kalangan remaja dan orang dewasa muda. Fokus utama studi ini adalah pada perempuan usia utama (prime age), kelompok yang biasanya diabaikan dalam komponen literatur upah minimum.

Penelitian ini menemukan bukti kuat efek kerja merugikan antara perempuan dewasa dan partisipasi yang lebih rendah, bahkan jika efek pengangguran dimatikan. Meskipun beberapa temuan yang serupa dengan Neumark dan Wascher untuk peran lembaga pasar dan kebijakan tenaga kerja, tidak ditemukan pola yang sama dalam data kelembagaan khususnya, penelitian ini menemukan efek disemployment kuat di negara-negara dengan sedikit pengaturan di pasar.

Studi lain terkait dengan upah minimum adalah penelitian yang dilakukan oleh (Pratomo, 2010) dalam "The Effect of Changes in Minimum Wage on Employment In The Covered and Uncovered Sectors In Indonesia" dengan menggunakan data tahun 1989-2003 dan metode pooled cross-sectional time series. Seluruh persamaan membedakan penyerapan tenaga kerja di daerah perkotaan dan perdesaan juga memberikan pengaruh positif terhadap penyerapan tenaga kerja.

\section{PENUTUP \\ Kesimpulan}

Berdasarkan pembahasan maka kesimpulan dalam penelitian ini adalah upah minimum berpengaruh secara negative terhadap penyerapan tenaga kerja bidang industri di Indonesia periode tahun 2012-2017. Hal ini berarti bahwa secara umum kenaikan upah minimum akan menyebabkan berkurangnya jumlah tenaga kerja bidang industri di Indonesia periode 2012-2017. Sedangkan variabel kontrol angkatan kerja memberikan pengaruh positif terhadap penyerapan tenaga kerja.

Berdasarkan pembahasan maka kesimpulan dalam penelitian ini adalah upah minimum berpengaruh secara negative terhadap penyerapan tenaga kerja bidang industri di Indonesia periode tahun 2012-2017. membedakan penyerapan tenaga kerja pria dan wanita. Hasilnya menunjukkan bahwa: 1) kenaikan upah minimum menurunkan kesempatan kerja di sektor covered dan meningkatkan kesempatan kerja di sektor uncovered. Terdapat efek perpindahan dari sektor covered ke sektor uncovered.

Penelitian ini juga menemukan bahwa efek perpindahan lebih besar pada tenaga kerja wanita, hal ini mengindikasikan bahwa tenaga kerja wanita lebih banyak terkena dampak dari kenaikan upah minimum. 2) Dibandingkan dengan daerah perkotaan, efek kenaikan upah minimum di perdesaan jauh lebih rendah, hal ini mengindikasikan bahwa upah minimum lebih sedikit efeknya, pada sektor pertanian tradisional.

Pusposari (2010), dalam "Analisis Pengaruh Upah Minimum Terhadap Kesempatan Kerja Sektor Industri di Jawa Timur ", menggunakan dua 
variabel kontrol yaitu PDRB merupakan variabel kontrol dari sisi permintaan dan angkatan kerja dari sisi penawaran dan menggunakan data panel 29 kabupaten dan 9 kota di Jawa Timur. Hasilnya menunjukkan bahwa dengan metode fixed effect kenaikan upah minimum berpengaruh negatif terhadap kesempatan kerja di sektor industri di Jawa Timur.

Penelitian (Chengis, Dube, Lindner and Zipperer, 2019) yang berjudul "The Effect Of Minimum Wage For Low WageWorker" dimana ditemukan jumlah keseluruhan pekerjaan berupah rendah tetap tidak berubah selama 5 tahun setelah kenaikan upah minimum. Akan tetapi penelitian ini juga menemukan beberapa bukti berkurangnya lapangan kerja di sector perdagangan, ditunjukkan pula bagaimana dampak pengurangan ketenagakerjaan secara keseluruhan di tempat pekerjaan yang memungkinkan cara yang transparan dan masuk akal untuk penilaian upah.

Maka Implikasi praktis hasil penelitian ini adalah dalam penentuan kebijakan strategis bahwa ketika upah minimum meningkat maka penyerapan tenaga kerja di bidang industri akan menurun, sebaliknya jika upah minimum turun maka penyerapan tenaga kerja bidang industri menjadi meningkat. Hal ini tentunya menjadi pertimbangan kepada pembuat kebijakan ketika menetapkan upah minimum pada tiap daerah, karena akan berdampak pada penurunan penyerapan tenaga kerja oleh industri dikarenakan menurunnya kemampuan industri maka perlu dipikirkankan formula yang tepat untuk menentukan angka yang tepat agar kebijakan tersebut tidak membawa dampak negatif secara luas.

\section{Keterbatasan dan Rekomendasi untuk Penelitian Selanjutnya}

Penelitian ini hanya melihat pengaruh upah minimum terhadap penyerapan tenaga kerja dengan analisis regresi panel statis sehingga tidak dapat memasukkan lag pada variable dependent dan jika dipaksakan hasilnya akan bias.

Untuk itu untuk penelitian selanjutnya dapat menggunakan analisis regresi panel dinamis dengan memasukkan lag pada variabel dependen maka menghilangkan masalah endogenitas pada regresi panel statis.

Kebijakan Upah Minimum Propinsi (UMP) tetap diperlukan sebagai acuan penentuan upah yang layak bagi pekerja utamanya bidang industri akan tetapi perlu diimbangi dengan kebijakan lain seperti (1) kemudahan akses modal bagi pengusaha, (2) penurunan pajak output, dan (3) peningkatan produktivitas sehingga perusahaan mampu meningkatkan kapasitasnya dan meningkatkan produksi dengan biaya lebih rendah.

\section{DAFTAR PUSTAKA}

Addison, J.T. and Azturk, O.D., 2010. "Minimum Wages, Labor Market Institutions, and Female Employment \& Unemployment; Cross Country Analysis”. IZA.DP No.5162. www.papers.ssrn.com.

Aulia, Telisa. 2004. Modul Pelatihan Ekonometrika. Surabaya: Fakultas Ekonomi

Bellante. D. and Jackson. M., 1990, "Ekonomi Ketenagakerjaan”. LPFE-UI, Jakarta

Borjas, George J. 2000. "Labor Economics" Singapore Mc. Graw.Hill-Book.Co.

Chengis, Dube, Lindner and Zipperer.2019. The Effect Of Minimum Wage ForLow Wage Worker. The Quartely Journal of Economic,Vol.134, Ed 3, August 2019,p.1405-1454. https://doi.org/10.1093/qje/qiz014

Ghozali. Imam, 2013. Aplikasi Analisis Multivariat dengan Program SPSS. Ketujuh. Semarang: Badan Penerbit Universitas Diponegoro

Gujarati, Damodar N. 2003. Basic Econometricts. International Edition. New York. Mc.GrawHill Companies.Inc

Lemos, Sara. 2009. "Minimum Wage Effects in Developing Country". Labour Economics, Volume 16, Issue 2, April 2009, Pages 224237

Macpherson, Brue, McConnell. 2003. "Contemporary Labor Economics" McGraw-Hill Companies Inc.

Marginean and Chenic, 2013. "Effect Of Raising Minimum Wage: Theory, Evidence and Future Challenge. Procedia Economics and Finance 6 (2013) 96-102

Nachrowi, Djalal N. dan Usman, Hardius. 2002. Penggunaan Tehnik Ekonometri. Edisi Revisi.PT Raja Grafindo Persada.Jakarta

Pratomo, Devanto. 2010. "The Effects of Changes In Minimum Wage on Employment In The Covered and Uncovered Sectors In Indonesia".Journal of Indonesian Economy and Business. Volume 25, Number 3.hal.261-273

Pusposari, 2010, "Analisis Pengaruh Upah Minimum Terhadap Kesempatan Kerja Sektor industri". Jurnal Iqtishoduna Volume 6. No.1. ISSN: $1829-524 X$. 